\title{
Leaching of Contamination from Stabilization/Solidification Remediated Soils of Different Texture
}

\author{
Juris Burlakovs ${ }^{1}$, Raimonds Kasparinskis ${ }^{2}$, Maris Klavins ${ }^{3},{ }^{1-3}$ University of Latvia
}

\begin{abstract}
Development of soil and groundwater remediation technologies is a matter of great importance to eliminate historically and currently contaminated sites. Stabilization/solidification (S/S) refers to binding of waste contaminants to a more chemically stable form and thus diminishing leaching of contamination. It can be performed using cement with or without additives in order to stabilize and solidify soil with the contamination in matrix. A series of experiments were done to determine leaching properties of spiked soils of different texture bound with cement. Results of experiments showed, that soil texture (content of sand, silt and clay particles) affects the leaching of heavy metals from stabilized soils.
\end{abstract}

Keywords - stabilization/solidification, heavy metals, remediation, soil texture, leaching tests

\section{INTRODUCTION}

Development of soil remediation technologies is a matter of great importance to eliminate historically and currently contaminated sites because pollution deteriorates environmental quality and possibilities of site operation [7]. The aim of remediation activities is to transform contaminated land into useful one, to conserve land resources, to improve environmental conditions in the contaminated site and around it, to reduce risks to humans and the environment. Remediation means actions taken to clean-up, mitigate, correct, abate, minimize, eliminate, control and contain or prevent a release of a contaminant into the environment in order to protect human health and the environment, including actions to investigate, study or assess any actual or suspected release [21].

Stabilization / solidification (S/S) technologies are based on the treatment of contaminated soils with materials such as cements and siliceous pozzolans and it can be employed in situ or to the excavated material. As a result, the mobility of the contaminant is reduced by physical-chemical processes. Solidification of the polluted substrate with cement restricts its contact with groundwater and air. Cement and siliceous pozzolans react with metals and cause the formation of hydroxides, carbonates and silicates of very low solubility. This treatment is not efficient for heavy metals that form soluble hydroxides or anion species [12].

$\mathrm{S} / \mathrm{S}$ technologies have been used for decades as the final treatment step prior to the disposal of both radioactive and chemically hazardous wastes. The stabilization refers to an alteration of waste contaminants to a more chemically stable form, thereby resulting in a more environmentally acceptable waste form. Typically, the stabilization processes also involve some form of physical solidification [15].

The environmental impact caused by the materials is not determined by their total content of pollutants, but by the amount of pollutants that water can dissolve and leach into the soil, thereby reaching the surface and/or groundwater $[11 ; 14]$.

Natural soils are often complex assemblages of soil fractions, components and possibly contaminants, and S/S treatment introduces new components which react through complex chemical interactions to produce more stable forms with less mobile components. However, long-term effectiveness and chemical durability of S/S treated materials are still not well known [4]. This creates a scenario where evaluations of stabilized material are undertaken without an understanding of the interactions and controlling factors [10].

Leaching time could represent one of the most important factors that influence the release of metals during a batch test. The time may influence the quantity of contaminant leached, unless equilibrium conditions are established [8].

Different tests of varying complexity and purpose are needed to address the variety of questions that can be met in practice, as outlined in detail by Kosson et al. [11]. Leaching under natural conditions resulting from rainfall in on-site applications would be less than the values observed in laboratory tests. However, such tests could provide information on leaching behavior under special conditions or to provide information on the available amount of a contaminant for leaching [8].

The aim of this study is to give an assessment of heavy metal leaching from $\mathrm{S} / \mathrm{S}$ remediated soils depending on the granulometric composition or soil texture. Thus, leaching behavior of copper was analyzed by implementing batch leaching procedure to stabilized samples under laboratory conditions.

\section{MATERIALS AND METHODS}

Mineral soil samples were collected in field works from 10 soil profiles of varied soil granulometric composition or soil texture, determined according to guidelines for soil description $[20 ; 1]$. As can be seen from Table I, soils had been taken in order to represent various soil textural classes, covering wide range of spectrum for sand, silt and clay proportion.

At the Soil Laboratory of the Faculty of Geography and Earth Sciences, University of Latvia, air-dried soil samples were sieved through a $2-\mathrm{mm}$ sieve. To determine particle sizes, samples were treated with $0.1 \mathrm{M} \mathrm{NaOH}$ to break down 
aggregates. Sands were sieved and fractions finer than 0.05 $\mathrm{mm}$ were determined by pipette analysis [2]. On the basis of the USDA soil texture classes, the fractions from 0.063 to 2.0 $\mathrm{mm}$ were classified as sand, those from 0.002 to $0.063 \mathrm{~mm}$ were classified as silt, and those finer than $0.002 \mathrm{~mm}$ were classified as clay [19] (see Tab. 1). The percentage of sand, silt and clay was calculated from fine earth $(<2 \mathrm{~mm}$ fraction). Soil $\mathrm{pH}_{\mathrm{KCl}}$ was measured with a glass electrode in $1 \mathrm{M} \mathrm{KCl}$ (1:2.5 mass-to-volume ratio) in triplicate. Afterwards samples were sieved again and weighted for two different procedures: 10 samples were spiked with copper sulphate in order to apply known contamination of $300 \mathrm{mg} / \mathrm{kg}$ in those, but 10 samples of the same soil were not. All 20 samples were bound with ordinary Portland cement (class 500) with the mixing ratio 10:1 (10\%).

The primary purpose of Portland cement grade PC500-D20 (CEM II/A-S 42,5N) is fabrication of concrete and reinforced concrete structures, surface, underground and underwater structures affected by fresh water. It is also used for building mortars preparation. Portland cement clinker is manufactured by burning at high temperature a raw meal consisting mainly of limestone and clay [9].

TABLE I

GRANULOMETRIC COMPOSITION OF ANALYSED SOIL SAMPLES

\begin{tabular}{|c|c|c|c|c|c|}
\hline Nr. & Clay $(\%)$ & Silt $(\%)$ & Sand $(\%)$ & Soil textural classes & $\begin{array}{c}\mathrm{pH}_{\mathrm{KCl}} \\
\text { mean value }\end{array}$ \\
\hline 1 & 11.10 & 26.70 & 62.60 & sandy loam & 4.97 \\
\hline 2 & 18.60 & 28.90 & 52.50 & sandy loam & 5.69 \\
\hline 3 & 12.50 & 33.70 & 53.80 & sandy loam & 4.52 \\
\hline 4 & 9.80 & 27.40 & 62.80 & sandy loam & 4.88 \\
\hline 5 & 15.20 & 48.20 & 36.60 & loam & 6.08 \\
\hline 6 & 13.70 & 36.70 & 49.60 & loam & 5.10 \\
\hline 7 & 15.60 & 36.00 & 48.40 & loam & 6.54 \\
\hline 8 & 14.10 & 50.00 & 35.90 & silt loam & 5.24 \\
\hline 9 & \multicolumn{4}{|c|}{ clay* } & not determined \\
\hline 10 & \multicolumn{4}{|c|}{ sand* } & not determined \\
\hline
\end{tabular}

* - determined in the field according to guidelines for soil description [20;1]

In recent years, an increase in the content of trace elements such as heavy metals in cement has been observed [18; 3]. It can influence the heavy metal content in bound samples therefore: 10 samples were prepared spiked with known contamination, but other 10 of same original granulometric composition without it. All bound with cement samples were left for 10 days of stabilization and solidification procedure in special molds having normal pressure and temperature $+20^{\circ} \mathrm{C}$. After 10 days of solidification, the samples were taken out of molds, crushed and sieved through $2 \mathrm{~mm}$ sieve and carefully mixed for the homogenous spread of contamination in each sample.

During the batch leaching test vessels were filled with distilled water till a liquid-to-solid-ratio of 10:1 (referred to the dry sample). Under continuous agitation at the rate 100 RPM, the batch leaching test was done for samples with agitation time periods of 1,4 and 24 hours. The $\mathrm{pH}_{\mathrm{H} 2 \mathrm{O}}$ level was measured for all samples after each period. After this time the solution is let to set down for about 10 minutes. For the determination of inorganic compounds the solution was filtered through a $0,45 \mu \mathrm{m}$ filter. Afterwards content of leached metals was determined by atom absorption spectrometry method.

Fig. 1 and 2 depict results with already calculated $\mathrm{Cu}$ mass losses from samples, using the relevance L/S 10:1.

\section{RESULTS AND DISCUSSION}

Setting time of a cementitious mixture is referred to as the period when water is introduced into the mixture system to the onset of hardening. Final setting time is defined as that at which the 5-mm cap ring left no noticeable mark when placed on the surface of the mortar mixture [17]. Stabilized / solidified waste acceptance criteria can be used to evaluate the effectiveness of the treatment. This criterion is chosen because $\mathrm{S} / \mathrm{S}$ technology is widely used for treatment and two main parameters are measured for determination of the effectiveness of remediation - unconfined compressive strength (UCS) and leachability limits. UCS is not the point of the study, but regulatory leachability limits are most important in this case, in order to see the effectiveness of binding. Therefore regulatory limits at a disposal site in the United Kingdom [16] is given, which is $5 \mathrm{mg} / \mathrm{L}$ or comparing to results in fig. 1 and 2 , would be $50 \mathrm{mg} / \mathrm{kg}$, if the L/S ratio 10 is applied like in this study case.

The $\mathrm{pH}_{\mathrm{H} 2 \mathrm{O}}$ values of all leachates were essentially alkaline and during the agitation $\mathrm{pH}_{\mathrm{H} 2 \mathrm{O}}$ was increasing in all cases, this trend can be easily seen in results of Table II.

Copper concentration in leachates of crushed and sieved samples, which were agitated for different time periods is increasing with time, this trend is obvious for natural samples with the binder as well as for spiked samples with $\mathrm{Cu}$ and bound with cement. Fig. 1 and 2 depict results with already calculated $\mathrm{Cu}$ mass losses from samples, using the relevance L/S 10:1. 
TABLE II

PH RESULTS AT BATCH LEACHING TEST FOR BOUND SOILS NOT SPIKED (N) AND SPIKED WITH COPPER (P) OF 300 MG/KG CONCENTRATION

\begin{tabular}{|c|c|c|c|c|c|c|}
\hline No. & Sample & Soil textural classes & start $\mathrm{pH}_{\mathrm{H} 2 \mathrm{O}}$ & $\begin{array}{c}\text { pHH2O after } 1 \mathrm{~h} \\
\text { agitation }\end{array}$ & $\underset{\text { agitation }}{\mathbf{p H}_{\mathrm{H} 2 \mathrm{O}} \text { after } 4 \mathrm{~h}}$ & $\underset{\text { agitation }}{\mathrm{pH}_{\mathrm{H} 2 \mathrm{O}} \text { after } 24 \mathrm{~h}}$ \\
\hline \multicolumn{7}{|c|}{ Not spiked samples 1-10 } \\
\hline 1 & $\mathrm{~N}-1$ & sandy loam & 11.28 & 11.59 & 11.83 & 11.86 \\
\hline 2 & $\mathrm{~N}-2$ & sandy loam & 11.62 & 11.65 & 11.90 & 12.07 \\
\hline 3 & $\mathrm{~N}-3$ & sandy loam & 11.23 & 11.36 & 11.65 & 11.92 \\
\hline 4 & $\mathrm{~N}-4$ & sandy loam & 10.97 & 11.23 & 11.52 & 11.83 \\
\hline 5 & $\mathrm{~N}-5$ & Loam & 11.00 & 11.15 & 11.32 & 11.66 \\
\hline 6 & N-6 & Loam & 11.30 & 11.60 & 11.72 & 11.83 \\
\hline 7 & $\mathrm{~N}-7$ & Loam & 10.83 & 11.11 & 11.41 & 11.44 \\
\hline 8 & $\mathrm{~N}-8$ & silt loam & 10.61 & 10.69 & 10.82 & 11.40 \\
\hline 9 & N-9 & Clay & 11.02 & 11.36 & 11.75 & 12.10 \\
\hline 10 & $\mathrm{~N}-10$ & Sand & 10.77 & 11.04 & 11.27 & 11.43 \\
\hline \multicolumn{7}{|c|}{ Spiked samples with $\mathrm{Cu}(300 \mathrm{mg} / \mathrm{kg}) 1-10$} \\
\hline 11 & $\mathrm{P}-1$ & sandy loam & 10.73 & 10.99 & 11.38 & 11.52 \\
\hline 12 & $\mathrm{P}-2$ & sandy loam & 11.04 & 11.24 & 11.53 & 11.97 \\
\hline 13 & P-3 & sandy loam & 10.58 & 11.03 & 11.17 & 11.32 \\
\hline 14 & P-4 & sandy loam & 10.78 & 11.10 & 11.28 & 11.58 \\
\hline 15 & P-5 & Loam & 10.42 & 10.61 & 10.97 & 11.15 \\
\hline 16 & P-6 & Loam & 10.59 & 10.76 & 11.21 & 11.24 \\
\hline 17 & P-7 & Loam & 10.37 & 10.62 & 10.94 & 11.01 \\
\hline 18 & P-8 & silt loam & 9.92 & 10.16 & 10.36 & 11.12 \\
\hline 19 & P-9 & Clay & 10.72 & 11.09 & 11.58 & 11.80 \\
\hline 20 & P-10 & Sand & 10.19 & 10.48 & 10.73 & 11.02 \\
\hline
\end{tabular}

In the diagram in Fig. 1 trends of leaching comparatively to the length of the agitation period for not contaminated (spiked with $\mathrm{Cu}$ and bound with cement) soil can be seen. Copper concentration in liquid is growing with the increasing of the agitation time. These values mostly can be taken as the reference for evaluation comparatively to the diagram in Fig. 2, which shows copper leaching from the spiked soil with $\mathrm{Cu}$ with determined concentration of $300 \mathrm{mg} / \mathrm{kg}$ and bound with cement.

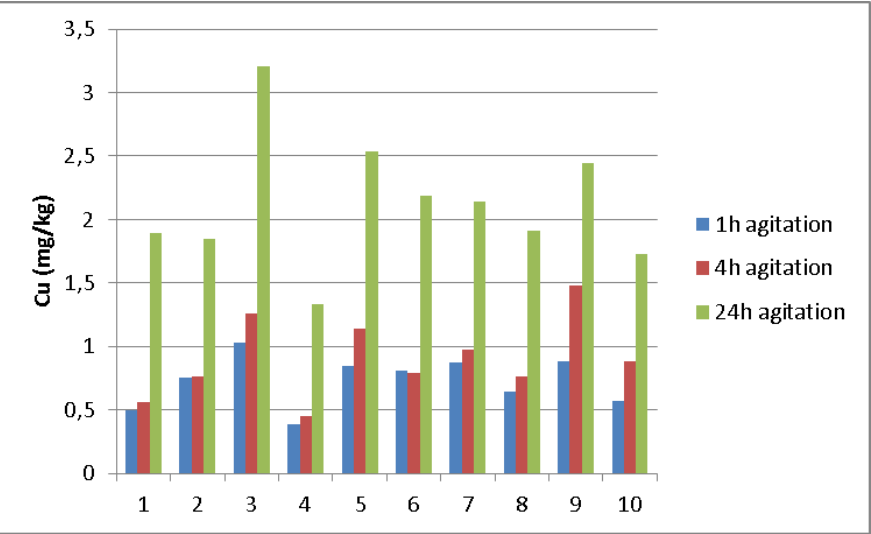

Fig. 1. Copper leaching $(\mathrm{mg} / \mathrm{kg})$ respectively to agitation time for not spiked with $\mathrm{Cu}$ soil, bound with $10 \%$ Portland cement. Contaminant mass loss grows with the function of time. Number of sample as in Table 1.

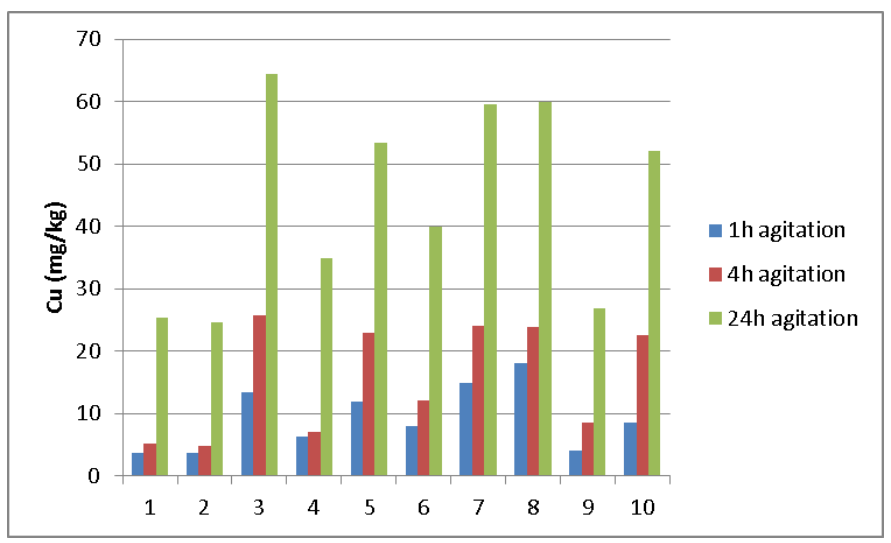

Fig. 2. Copper leaching $(\mathrm{mg} / \mathrm{kg})$ respectively to agitation time for spiked with $\mathrm{Cu}(300 \mathrm{mg} / \mathrm{kg})$ and bound with $10 \%$ Portland cement soil. Contaminant mass loss grows with the function of time. Numbers of samples as in Table 1.

Comparing leaching results in a time period, were observed, that there is a proportional difference between results gained from eluate after $1 \mathrm{~h}$ and $24 \mathrm{~h}$ both from not spiked and spiked soils bound with cement. The ratio between leached $\mathrm{Cu}$ in $24 \mathrm{~h}$ and amount in $1 \mathrm{~h}$ of agitation for not spiked bound soils varies from 2.46 to 3.78 (average 2.97), but for spiked with $\mathrm{Cu}-$ between 3.31 and 6.98 (average 5.38). The difference between results of $4 \mathrm{~h}$ and $1 \mathrm{~h}$ agitation has shown that faster leaching speed has been detected from samples nr. 3, 5, 9 and 10, 
which has very different soil particle size distribution. Possible that particle size in bound $\mathrm{S} / \mathrm{S}$ remediated soils has a little role in leaching process. Nevertheless sandy loam (samples 1-4) according the description of field notes itself has very heavy and dense structure as clays have. Results of leaching results at graph in Fig. 2 show trends, that diminished leaching can be outlined for samples 1, 2, 4 (heavy sandy loam) and 9 (clay). It is possible that contaminants as copper in this case is leaching less not because of particle size, but it is more connected with the presence of more clay minerals in bound matrix. Further experiments must be performed in order to gain more information about clay mineral additives, which would increase sorption capacity of contaminants. Another goal of soil cementing in matrix is to increase the $\mathrm{pH}$ in soil, what is diminishing efficiently the leaching speed of cationic heavy metals $[5 ; 6 ; 13]$. This study experiment included crushing and sieving of the bound matrix, thus itself increasing the possibility of contaminant leaching. In real examples physical stabilization of soil blocks as the solidified mass will have less leaching because of less intensive groundwater and precipitation impact to leaching as was performed during the intensive batch leaching test of $24 \mathrm{~h}$. Tank as well as column leaching tests can be applied in order to get additional results with less extreme leaching results closer to the real environmental model. This experiment has shown that less intense copper leaching is characteristic to soils with texture classes of sandy loam and clay.

\section{CONCLUSIONS}

Remediation of contaminated areas by stabilization / solidification (S/S) technology is closely connected with the development degree of engineering science and empirical knowledge supported by new experiments done in this field. Various leaching tests are provided in order to give information about behaviour of different contaminants in stabilized solidified soils. Leaching in S/S remediated soils is diminished, and it certifies effectiveness of this technology.

This study was performed to gain data about copper leaching in soils of different texture bound with ordinary Portland cement of class 500. Two series of leaching test were done for spiked and not spiked with copper soils, remediated by cement.

Results have shown that less intense copper leaching is characteristic to soils with texture classes of sandy loam and clay. Further experiments of $\mathrm{S} / \mathrm{S}$, leaching tests, compression tests as well as freeze-thaw tests must be performed for contaminated and spiked with trace elements soils in order to research trends of leaching and find better recipes of binder material.

\section{ACKNOWLEDGEMENTS}

This research was carried out with the help of European Social Fund (ESF). Special thanks to M. Dziluma and A. Kārklinga for the kind help with laboratory work performance.

\section{REFERENCES}

1. Kārkliňš, A. Augsnes diagnostika un apraksts. Latvijas Lauksaimniecības Universitāte, Jelgava, 2008, 336 lpp.

2. Van Reeuwijk, L.P. Procedures for Soil Analysis, 5th edition. Wageningen, 1995.

3. Achternbosch, M., Bräutigam, K.R., Hartlieb N., Kupsch, C., Richers, U., Stemmermann, P. Impact of the use of waste on trace element concentrations in cement and concrete. In: Waste Management Research, 2005; 23:328-37.

4. Bone, B.D., Barnard, L.H., Boardman, L.H., Carey, P.J., Hills, C.D., Jones, H.M., MacLeod, C.L., Tyrer, M. Review of scientific literature on the use of stabilisation / solidification for the treatment of contaminated soils, solid wastes and sludges. In: Environmental Agency, Science Report SC980003/SR2. Environmental Agency, UK, 2004.

5. Cocke, D.L., Mollah, M.Y.A. The chemistry and leaching mechanisms of hazardous substances in cementitious solidification/stabilization systems. In: Spence, R.D. (Ed.), Chemistry of Microestructure Solidified Waste Forms. Lewis Publishers, U.S.A., 1993, pp. 187-242.

6. Conner, J.R., Hoeffner, S.L. A critical review of stabilization/solidification technology. In: Environonment Science and Technology. 1998, 28: pp.397-462.

7. Directive 2008/1/EC of the European Parliament and of the Council of 15 January 2008 concerning integrated pollution prevention and control. Text with EEA relevance. Official Journal of the European Union, L 24/8, 29.1.2008

8. Galvin, A.P., Ayuso, J., Jiménez, J.R., Agrela, F. Comparison of batch leaching tests and influence of $\mathrm{pH}$ on the release of metals from construction and demolition wastes. In: Waste Management 32, 2012, pp. 88-95.

9. Gineys, N. Aouad, G., Damidot, D. Managing trace elements in Portland cement - Part I: Interactions between cement paste and heavy metals added during mixing as soluble salts. In: Cement \& Concrete Composites 32, 2010, pp. 563-570.

10. John, U.E., Jefferson, I., Boardman, D.I., Ghataora, G.S., Hills C.D. Leaching evaluation of cement stabilisation / solidification treated kaolin clay. In: Engineering Geology 123, 2011, pp. 315-323.

11. Kosson, D.S., Van der Sloot, H.A., Sanchez, F., Garrabrants, A.C. 2002. An integrated framework for evaluating leaching in waste management and utilization of secondary materials. In: Environ. Eng. Sci. 19 (3), pp. 159-204.

12. Lombi, E., Wenzel, W.W., Adriano, D.C. Soil Contamination, Risk Reduction and Remediation. In: Land Contamination \& Reclamation, 6 (4), 1998, 183-197. DOI: 10.2462/09670513.401

13. Malviya, R., Chaudhary, R. Factors Affecting Hazardous Wastes Solidification / Stabilization: A Review. In: Journal of Hazardous Material, 2006, 137 (1) pp. 267-276.

14. Polo, M.J., Domknguez, D., Girildez, J.V. 2005. Leaching of metals from residual contamination points in the basin of Guadiamar. VII Jornadas de Investigación en la Zona no Saturada del Suelo. La Coruńa (Spain). ISBN: 84-9749-171-8

15. Shi, C., Fernandez-Jimenez, A. Stabilization / Solidification of Hazardous and Radioactive Wastes with Alkali-activated Cements. In: Journal of Hazardous Materials, B137, 2006, pp. 1656-1663. DOI: 10.1016/j.hazmat.2006.05.008

16. Sollars, C.J., Perry, R. Cement-based stabilization of wastes: practical and theoretical considerations. In: J. Inst. Water Environ. 3, 1989, pp. 125-132.

17. Yin, C.Y., Mahmud, H.B., Shaaban, M.G. Stabilization/solidification of lead-contaminated soil using cement and rice husk ash, In: Journal of Hazardous Materials B137, 2006, pp. 1758-1764.

18. Zhang, J., Liu, J., Li, C., Nie, Y., Jin, Y. Comparison of the fixation of heavy metals in raw material, clinker and mortar using a BCR sequential extraction procedure and NEN7341 test. In: Cement and Conceter Research, 2008, 38: pp. 675-80.

19. FSCC (Forest Soil Co-Ordinating Centre), 2006. Manual IIIa: Sampling and Analysis of Soil. In: ICP Forests, 2006: Manual on methods and criteria for harmonized sampling, assessment, monitoring and analysis of the effects of air pollution on forests. UNECE ICP Forests Programme Co-ordinating Centre, Hamburg. p 26. with annexes; Available at: http://icp-forests.net/page/icp-forests-manual, Accessed: 27.03.2012

20. IUSS Working Group WRB. 2007. World reference base for soil resources 2006, first update 2007. World Soil Resources Reports 103. Rome: FAO. p $115 . \quad$ Available at: 
$2012 / 9$

http://www.fao.org/ag/agl/agll/wrb/doc/wrb2007_corr.pdf, Accessed 01.08.2012.

21. 9VAC20-160-10. Definitions. Virginia Register Volume 13, Issue 18, eff. June 26, 1997; amended, Virginia Register Volume 18, Issue 18, eff. July 1, 2002;. Accessed: 01.04.2011. Available at: http://leg1.state.va.us/cgi-bin/legp504.exe?000+reg+9VAC20-160-10, Accessed: 13.03.2012.

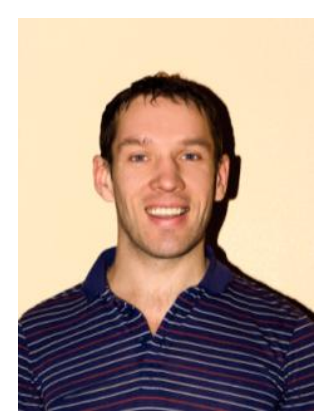

Juris Burlakovs is the doctoral student of Environmental Sciences at the University of Latvia. Particularly the scientific interest is focused on heavy metal contamination remediation technologies and applications of those in different geoecological conditions. Previously he has gained Master degrees in Environmental Management (2009) and Quaternary Geology and Geomorhology (2002) at the University of Latvia, has shortly studied environmental engineering at the University of Padova, Italy.

He works at Environmental Consultancy Bureau Ltd. in Riga as the Environmental Specialist, also has the private practice of drilling works for water supply issues. Earlier career is bound with geomagnetic research and geology.

$\mathrm{He}$ is the member of Latvian Association for Quaternary Research and Latvian Astronomical Society.

Address: Alberta Str. 10, LV-1014, Riga, Latvia

Phone: +37128469044

E-mail: juris@geo-it.lv

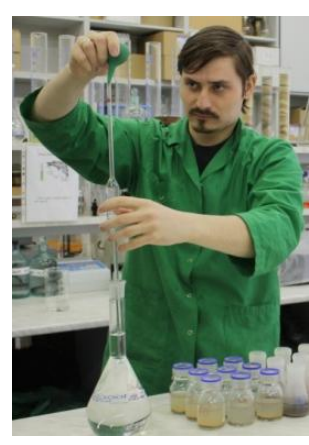

Raimonds Kasparinskis is the $\mathrm{PhD}$ student in Environmental Sciences at the Faculty of Geography and Earth Sciences, University of Latvia. In advance he graduated the bachelor (2005) and the master (2007) study programmes in Environmental Sciences. Main research interests are related to forest and agricultural soil research (the influence of environmental factors on soil morphological, physical and chemical properties, and soil forming processes) as well as land degradation. $\mathrm{He}$ is interested also in weather forecasting and meteorology.

$\mathrm{He}$ is researcher (participates in various scientific international and local research projects) and dean assistant in development affairs at the Faculty of Geography and Earth Sciences, University of Latvia. Prior to the University he worked as weather forecaster in Latvian Environment, geology and meteorology agency.

$\mathrm{He}$ is the member of Latvian Association for Quaternary Research.

Phone: +37126479040

E-mail: raimonds.kasparinskis@1u.lv

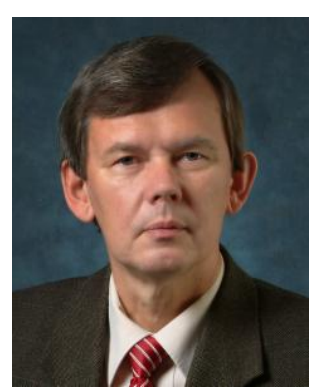

Maris Klavins (professor, Dr.hab.chem.) is head of Environmental science department of Faculty of Geography and Earth sciences, University of Latvia. M.Klavins has worked as head of Laboratory of sorbents in Institute of Applied biochemistry of Academy of Sciences USSR, Head of hydrochemistry group of Institute of biology and since 1992 is affiliated with University of Latvia. M.Klavins is member of editorial boards of 6 scientific journals, member of 3 societies related to environmental chemistry issues and full member of Academy of Sciences of Latvia. 